\title{
УДК: 57.085:633.34:631.5 https://doi.org/10.53040/gppb7.2021.14 ВИЗУАЛИЗАЦИЯ IN VIVO КЛУБЕНЬКОВ СОИ В ПОЛЕВЫХ УСЛОВИЯХ
}

\author{
Харчук Олег \\ Институт генетики, физиологии и защзиты растений, Кишинэу, Республика Молдова \\ e-mail:oleg.harciuc@igfpp.md
}

\begin{abstract}
Abstact
The possibility of non-destructive, without disturbing the viability of the whole plant, in vivo visualization of nodules formed on the roots of soybeans in field conditions has been shown.

Key words: Soybean, nodules.

Введение

Недеструктивные методики широко применяются при биологических исследованиях растений. В частности, недеструктивное измерение листовой поверхности позволяет проводить учеты в сезонной динамике на одних и тех же растениях, что, при одном и том же объеме работы, позволяет уменьшить разброс данных и увеличить статистическую достоверность результатов [1]. Исследования клубеньков, образующихся на корнях растений сои, обычно необратимо ликвидирует жизнеспособность как клубеньков, так и целого растения [2; 3]. В настоящей работе была поставлена задача изучить возможность в полевых условиях недеструктивной, без нарушения жизнеспособности целого растения, визуализации in vivo клубеньков на корнях растений сои.
\end{abstract}

\section{Материалы и методы}

Полевые опыты с растениями сои проведены в 2021 году на участке в Яловенском районе Молдовы, где в 2009-2011 гг. проводили исследования с сортами томатов [4]. Содержания химических элементов (Cl, S, Ca, Mg, и др.) определяли на рентгеновском спектрометре VRA-30, a влажность и электропроводность почвенной влаги измеряли фитомонитором PM-11 с использованием датчика SMS-TE. Опытный участок характеризуется плохим качеством воды $(1,25$ г/л), включая в качестве доминирующих следующие ионы: $\mathrm{Na}+-$ 5,6 мг-экв/л, Cl- - 7,0 мг-экв/л, SO42-4,7 мг-экв/л. Содержание $\mathrm{Mg} 2+$ - 4,7 мг-экв/л, Сa2+ -2,5 мг-экв/л. На делянке без пахоты электро-

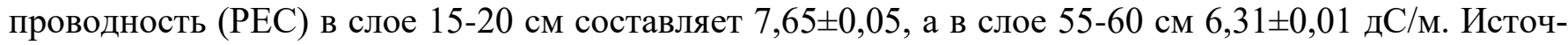
ники воды для орошения отсутствуют.

В последние предшествующие годы (2018-2020) опытный участок был использован для опытов с растениями сои с внесением в почву культуры ризобактерий Bradyrhizobium japonicum штамм RD2 из коллекции Института микробиологии и биотехнологии (предоставлен доктором биологии В.Тодераш). В 2021 году культуру ризобактерий в почву не вносили, а сев сои на площади 50 м $^{2}$ при междурядье 50 см (плотность ценоза 18 растений на квадратный метр) провели необработанными семенами перспективной формы сои А2, выявленной на полях Института генетики, физиологии и защиты растений в опытах 2018-2019 гг. Сев сои в 2021 г. провели необработанными семенами с учетом стимуляции клубенькообразования предысторией выращивания сои на опытном участке [5]. Для описания этапов органогенеза сои использовали общепринятую классификацию [6].

Для недеструктивной in vivo визуализации клубеньков на корневой системе сои применяли многофункциональный семипозиционный (с изменением угла распыла воды) оросительный пистолет-распылитель ҮТ-8963 фирмы ҮАТО (Польша). Воду в распылитель подавали под необходимым давлением портативным насосом SCW 400 S Steinberg (Германия). Воду, использованную для отмывки, отводили в сторону.

Листовую поверхность (ЛП) растений сои определяли недеструктивным методом, при этом измеряли длину и ширину всех настоящих листьев [1]. Для определения площади каждого конкретного тройчатого листа использовали формулу Bakhshandeh et al. (2011): $\mathrm{S}, s m^{2}=1,923 *(\mathrm{~L}, s m) *(\mathrm{D}, s m)$ - 4,869 [7]. Полную ЛП (всего растения) вычисляли как сумму площадей всех листьев больше $5 \mathrm{~cm}^{2}$ [8]. В период наполнения семян учитывали количество бобов раздельно по каждому узлу нижней (кустистой) части растений и верхней части центрального побега (стебля). Оценку генеративной 
продуктивности ЛП растений делали в стадии R5 на основе учетов величины ЛП и количества бобов на одно растение. Биометрическую оценку ценоза сои проводили по 10ти растениям.

\section{Результаты и обсуждение}

Предыстория участка, где в 2020 году в почву вносили культуру ризобактерий, позволяла ожидать хорошего клубенькообразования на корнях даже при севе необработанными семенами [5]. Первоначальные опыты, с отмывкой корневой системы на большую глубину, на всю толщину пахотного горизонта (0-30 см), показали преимущественную локализацию клубеньков в поверхностном слое чернозема, не глубже 10 см (Фиг. 1).

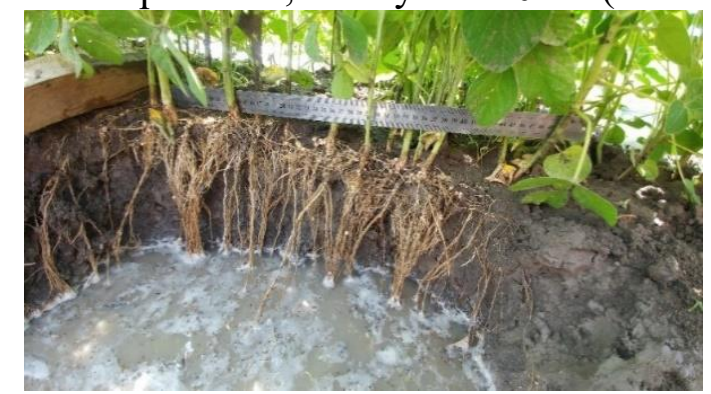

Фиг. 1. Визуализация клубеньков в срок 85 дней после сева (ДПС).

Срок 85 ДПС соответствует стадии R2, полного цветения [6]. Полученный результат позволил в дальнейших исследованиях уменьшить глубину отмывки корневой системы для визуализации in vivo клубеньков до глубины не более 10 см (Фиг. 2).

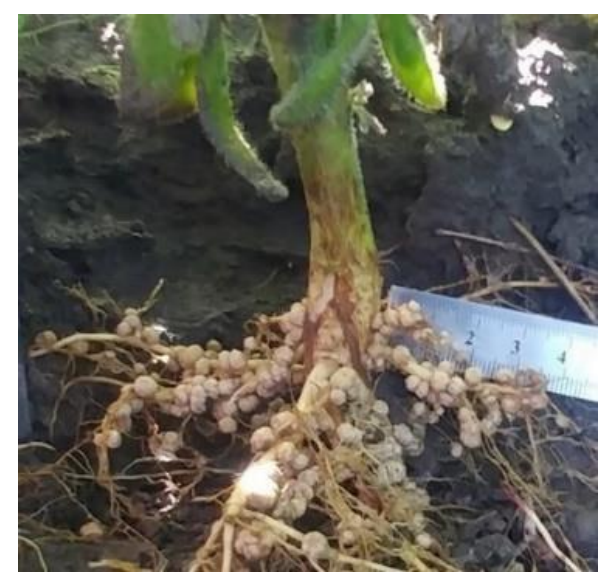

Фиг. 2. Визуализация клубеньков при локальной отмывке корневой системы нативного растения сои (срок 113 ДПС). Ориентация линейки - с юга на север

Тем не менее, даже при столь глубокой отмывке, как на Фиг. 1, дальнейшие сезонные наблюдения показали полную жизнеспособность растений после визуализации части корневой системы. При этом на нашем участке мы наблюдали преимущественную локализацию клубеньков вблизи растения (Фиг. 2). Для растения на Фиг. 2 срок 113 ДПС соответствует границе между генеративными стадиями онтогенеза R4 и R5.

После прекращения визуализации in vivo клубеньков (смытую почву вокруг гипокотиля замещали свежей почвой) растения полностью сохранили свою жизнеспособность, о чем, в частности, свидетельствует их вид через 2 недели после визуализации части корневой системы, в срок 127 ДПС (Фиг. 3), в стадии R6.

Фиг. 3. Апикальная часть растения сои (то же растение на Фиг. 2) через две недели после визуализация in vivo клубеньков (срок 127 ДПС).

Полное сохранение жизнеспособности растений сои в поле после визуализации in vivo клубеньков доказывается и биометрическими учетами (Табл. 1 и 2).

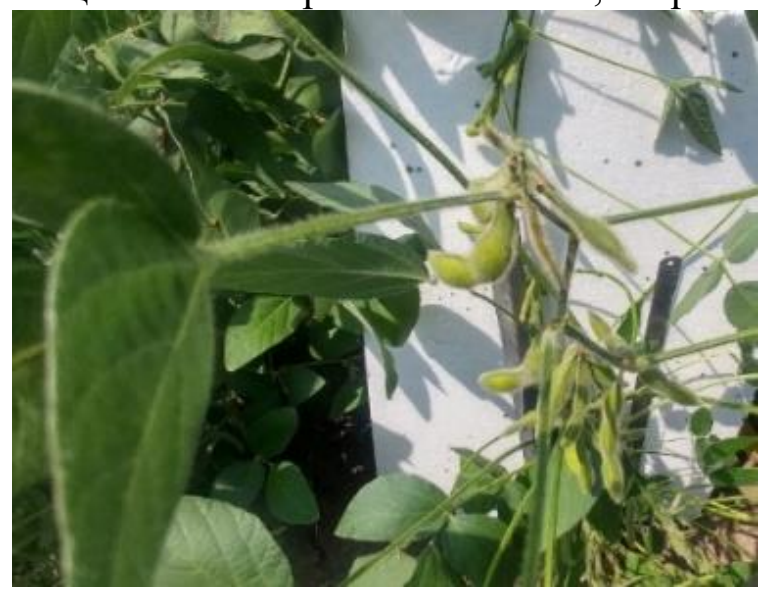


Таблица 1. Продуктивность листовой поверхности (ЛП) нативных растений и растений с предшествующей* визуализацией in vivo клубеньков

\begin{tabular}{|c|c|}
\hline Вариант растений сои в ценозе (127 ДПС) & Продуктивность ЛП, бобов на $1 \mathrm{dm}^{2}$ ЛП \\
\hline нативные & $3,13 \pm 0,13$ \\
\hline после визуализации клубеньков & $3,00 \pm 0,51$ \\
\hline
\end{tabular}

*Визуализацию in vivo проводили в сроки от 85 до 113 ДПС (стадии от R2 до R5).

Данные Таблиц 1 и 2, как и Фиг. 3 показывают, что процедура визуализации клубеньков in vivo не ухудшала физиологическое состояние растений, о чем прежде всего говорит неизменность генеративной продуктивности листовой поверхности растений, как нативных, так и испытавших предшествующую визуализацию части корневой системы.

Таблица 2. Продуктивность листовой поверхности (ЛП) растения перспективной формы сои А2 (127 ДПС) после предшествующей* визуализации in vivo клубеньков (Фиг. 2).

\begin{tabular}{|c|c|c|}
\hline Биометрические параметры растения сои в ценозе & Продуктивность ЛП, бобы/ $\partial \mu^{2}$ \\
\hline количество бобов, шт/растение & 139 & \multirow{2}{*}{3,83} \\
\hline листовая поверхность, $\partial \mu^{2} /$ растение & 36,3 & \\
\hline
\end{tabular}

*Визуализацию in vivo проводили в срок 113 ДПС.

Растение, визуально имеющее большое количество клубеньков (Фиг. 2), не только сохранило свою жизнеспособность, но и проявило наибольшую (и очень высокую) величину генеративной продуктивности листовой поверхности - 3,83 боба на 1 дм ${ }^{-2}$ листовой поверхности растения.

\section{Выводы}

Показана возможность недеструктивной, без нарушения жизнеспособности целого растения, визуализации in vivo клубеньков, образованных на корнях растений сои в полевых условиях.

Исследования проведены в рамках проекта Государственной Программы 20.80009.7007.16 «Синергизм между природными факторами и экологически безвредными микробиологическими средствами регулирования плотности популяции вредителей для защиты сельскохозяйственных культур в традиционном и органическом сельском хозяйстве», финансируемой Национальным Агентством по Исследованиям и Развитию.

\section{Литература}

1. ХАРЧУК, О.А., КИРИЛЛОВ, А.Ф., 2019. Недеструктивное определение листовой поверхности растений сои в сезонной динамике. // Евразийский Союз Ученых. 2 (59), ч. 5, стр. 33-36. https://euroasiascience.ru/wp-content/uploads/2019/03/33-36-Kharchuk-O.A.-Kirillov-A.F..pdf (visited 25.08.2021).

2. SAEKI, Y, AKAGI, I, TAKAKI, H, NAGATOMO, Y., 2000. Diversity of indigenous Bradyrhizobium strains isolated from three different Rj-soybean cultivars in terms of randomly amplified polymorphic DNA and intrinsic antibiotic resistance. Soil Science and Plant Nutrition 46:917-926. DOI: 10.1080/00380768.2000.10409157.

3. TAHIR, M.M., ABBASI, M.K., RAHIM, N., KHALIQ, A. and M.H. KAZMI, 2009. Effect of Rhizobium inoculation and NP fertilization on growth, yield and nodulation of soybean (Glycine max L.) in the sub-humid hilly region of Rawalakot Azad Jammu and Kashmir, Pakistan. African Journal of Biotechnology Vol. 8 (22), pp. 6191-6200.

4. ХАРЧУК, О.А., НИКУЛАЕШ, М.Д., 2011. Продуктивность сортов томатов при сбережении осадков в условиях потенциального водно-солевого стресса // В : Культурные растения для устойчивого сельского хозяйства в ХХІ веке (иммунитет, селекиия, интродукция). К 110-летию академика ВАСХНИЛ и Россельхозакадемии М.С. Дунина. Москва, том IV, часть 1, стр. 403-410

5. HALWANI, M., RECKLING, M., EGAMBERDIEVA, D., OMARI, R.A., BELLINGRATH-KIMURA, S.D., BACHINGER, J. and R. BLOCH, 2021. Soybean Nodulation Response to Cropping Interval and Inoculation in European Cropping Systems. Frontiers in Plant Science. DOI: 10.3389/fpls.2021.638452. Available from: https://www.researchgate.net/publication/352123956_Soybean_Nodulation_Response_to_Cropping_Interval_a nd_Inoculation_in_European_Cropping_Systems [visited 25.08.2021]

6. FEHR, W.R., CAVINESS, C.E., 1977. Stages of Soybean Development.Cooperative Extension Service. Agriculture and Home Economics Experiment Station IOWA STATE UNIVERSITY of Science and Technology Ames, Iowa, 11 p.

7. BAKHSHANDEH, E., KAMKAR, B. \& TSIALTAS, J.T., 2011. Application of linear methods for estimation of leaf area in soybean [Glycine max (L.) Merr,] // Photosynthetica 49, p. 405.

8. CHIERA, J., THOMAS, J. and RUFTY, T., 2002. Leaf initiation and development in soybean under phosphorus stress // J. Exp. Bot. 53 (368), pp. 473-481. 